\title{
A TURISZTIKAI DESZTINÁCIÓK ÉLETCIKLUS-PROBLEMATIKÁJA: AZ ORFỨI PÉLDA
}

\author{
AUBERT ANTAL - GONDA TIBOR \\ - JÓNÁS-BERKI MÓNIKA - MÓKUSNÉ PÁLFI ANDREA \\ THE PROBLEMS OF THE LIFE CYCLES OF \\ TOURISM DESTINATIONS: THE EXAMPLE OF ORFÚ
}

\begin{abstract}
This article demonstrates the complex issue of the life cycle and renewal of destinations through the example of a destination in Hungary. These days, due to the ever-increasing competition among destinations both in domestic and international markets, this is the central issue in the development and management of destinations, especially where recreational and excursionist functions are dominant. The target area chosen can be found in the hinterland of a regional centre (Pécs), where, in addition to recreational functions, the repositioning efforts of the last ten years led to the more and more important role of sport tourism and supplementary tourism products like ecotourism, heritage tourism, and festival tourism. This versatility provides another challenge for the actors of the destination, as the main pillars of the renewal of the destination concern all actors in the destination (inhabitants, non-governmental organisations, service providers, and municipal self-government) in some way. During the research we thus also carried out a questionnaire survey with the local stakeholders (inhabitants and municipal self-government) and actors interested in tourism (holiday home owners, service providers), in addition to the processing of secondary data sources.
\end{abstract}

Keywords: destination, destination life cycle, destination management, Orfü

\section{Bevezetés}

A desztinációk kérdéskörét a nemzetközi turisztikai szakirodalom centrumában álló és sokoldalúan elemzett témái között tartjuk számon. Különösen az imázsfejlesztésre és pozícionálásra fókuszáló marketingkommunikáció (BuHALIS, D. 2000; ANHOLT, S. 2009; HORKAY N. 2003a, b; PAPP-VÁRY Á. 2009), a versenyképességet célzó menedzsment (KOZAK, M. 2002; TőzSÉR A. 2010; SzIVA I. 2014), az életciklus-modell érvényessége (HovinEN, G. 2002), valamint a fenntarthatóság biztosítása (LEE, K. 2001) sorolható a publikációkban leggyakrabban előforduló kérdések közé. Tanulmányunk egy magyarországi esettanulmányon keresztül igyekszik igazolni a desztináció-megújulás/megújítás komplexitását, amelyben természetesen az előzőekben felvetett kérdéskörök is érintettek lesznek.

A vizsgált desztináció Magyarország déli részén, Pécs város regionális centrum vonzáskörzetében, a Mecsek hegység északi előterében fekszik. A klasszikus életciklus-modellbe (BUTLER, R. W. 1980) nehezen illeszthető, hiszen a célterület rekreációs és turisztikai funkciókkal egyaránt rendelkezik, fél évszázados történetére, annak folyamatos fejlődésére, illetve megszakítottságára a társadalmi-politikai rendszerváltás (1990) nagy hatással volt. A rendszerváltás utáni piacvesztés (a külföldi vendégkör drasztikus csökkenése), a turisztikai trendek gyors változása (az alternatív turizmusformák növekvő népszerüsége, új desztinációk megjelenése), a fejlesztési források elérhetősége (EU-s támogatások), a turizmusirányítás paradigmaváltása (TDM-ek megjelenése), az önkormányzati szerepvállalás mind-mind olyan faktora volt a magyarországi turisztikai folyamatoknak, amelyek országosan, de helyi szinten is válaszút elé állították a kisebb-nagyobb desztinációkat. 
A stagnálás, majd a hanyatlás fázisából csak az utóbbi évtizedben megújuló orfűi desztináció a termékmegújuláson és az imázsváltáson túl a helyi társadalom (önkormányzat, civil szervezetek) aktivizálódásának is az iskolapéldája. Tanulmányunkban e komplex kérdéskör vizsgálatára vállalkoztunk, amelyben az életciklus-modell keretébe ágyazva tárgyaljuk a desztináció-megújulás problematikáját.

A kutatás során az alábbi 4 hipotézisünkból indultunk ki:

1. A jelentős rekreációs funkcióval is rendelkező turisztikai desztinációk életciklusa eltérhet a tisztán csak turisztikai funkcióval rendelkező desztinációk életciklusától.

2. A desztináció-megújítás eredményességét és gyorsaságát jelentősen befolyásolja, ha az attrakciófejlesztés, fogadóképesség-javulás és menedzsment-struktúrájának a fejlesztése egyaránt megvalósul.

3. A hanyatlás időszakában a vendégéjszakák számának csökkenését kis fáziseltolódással követi a szálláshely-kapacitás csökkenése is.

4. Az újrapozícionálás akkor lehet sikeres, ha valós és reális helyzetértékelésen nyugszik és olyan turisztikai termékek fejlesztésére fókuszál, amelyekben a desztinációnak relatív előnye van más desztinációkkal szemben.

Fontos tisztázni, hogy a tanulmányunkban az elemzések a KSH vendégéjszakaszám- és kínálati oldalt rögzítő adatain, valamint saját primer kutatásainkon alapulnak. A hazai turizmuskutatásokban - és még inkább a fogadóterületek turisztikai menedzsment gyakorlatában - nincs hagyománya a napi látogatószám vizsgálatának. Orfű esetében ez különösen fontos lenne, mivel itt a közel 300 lakóingatlanon kívül (amelyekben a kb. 1000 fôs lélekszámú lakosság él) csaknem 1000 üdülőingatlan található (GONDA T. et al. 2018). Ezeket többnyire a tulajdonosok és családtagjaik használják és az általuk Orfün töltött éjszakaszám - a polgármesteri hivatal és a TDM szakembereinek becslése alapján - 100-200 ezer közé tehetô, de mindenképpen jóval meghaladja a hivatalosan mért turisztikai vendégéjszaka-számot. Tanulmányukban GondA T. és munkatársai Orfü rejtett turizmusának további aspektusaira is rámutatnak (GoNDA T. et al. 2018). Fontos megemlítenünk a nem konvencionális értelemben vett turizmus jelentőségét is a desztinációban. Ezen azokat a turisták által végzett mozgásokat értjük, amelyek nem járnak éjszakai tartózkodással. Ilyen például a nemzetközi átutazó- vagy az egy napnál rövidebb idejú kirándulóturizmus. Ezeket az utazási formákat a láthatatlan turizmus kategóriájába sorolhatjuk (MichALKó G.-RÁTz T. 2013) Az Aquapark évi százezer fő feletti, a szabadstrandok és más attrakciók tízezres látogatószámaiból kiindulva, figyelembe véve továbbá a szinte egész évben megfigyelhető hétvégi kirándulóturizmus volumenét, valamint megismerve a polgármesteri hivatal és a TDM szakembereinek a véleményét, kijelenthetjük, hogy a napi látogatószám éves szinten több százezer főre tehetô. Nyilvánvaló, hogy Orfú láthatatlan turizmusa a magánüdülő́k forgalmának és a szép számú napi kirándulóforgalomnak köszönhetően igen jelentős. Ennek konkrét volumenét nagyon nehéz megbecsülni, így jelen tanulmányunkban erre nem is vállalkozunk.

\section{A desztináció-megújulás/megújítás elméleti háttere}

A desztinációk megújulása aktuális kérdése a világ turizmusának (FAULKNER, B. 2002). A turisztikai desztinációk életpályája (BuTLER, R. W. 1980) több jellemző alapján eltér a klasszikus, „közönséges” termékek görbéjétől, aminek egyik következménye, hogy a desztinációk többsége számára az elmúlt 50 év alatt viszonylag könnyú volt hosszabb távon is fenntartható növekedési rátát elérni (Ritchie, J. R. B.-CROUCH, G. I. 2000). Azonban az elmúlt évtizedeknek a turisztikai piacot és annak környezetét érintô változásai a desztinációk szintjén is mind többször vetik fel a megújulás kérdésének fontosságát (BuJOSA, A. 
et al. 2015), amiben az egész folyamat alapja a fenntarthatóság (HALL, D. 2009). KoTLER, PH. (2000) termék-megfiatalítási stratégiái (gyengeséget okozó tényezők, külső környezeti tényezők, márkanév, potenciális szegmentumok, fogyasztói érték) a turisztikai szektorban is általánosan érvényesek. Ennek megfelelően a termékéletciklus-menedzsment során a következő stratégiák merülnek fel: nagyobb termékmódosítások, a termék megítélésének módosítása, új elosztási csatornák, új használati módok. Modelljében BUTLER, R. W. (1980) a megújulásnak (rejuvenation) két útját említi meg: mesterséges attrakciófejlesztés keretében történő (pl. Atlantic City), illetve a korábban nem hasznosított, érintetlen természeti környezeten alapuló megújulást.

A desztináció-megújulás két alapvető módját különbözteti meg KovÁcs P. (2004) is: a visszahódító és az újrapozícionáló stratégia alkalmazását. A visszahódító stratégia keretében a meglevő és korábban is turisztikai céllal hasznosított erőforrás egy jelentősebb tőkeinjekció révén újul meg, korszerűsödik. Az újrapozícionálás során a szolgáltatások, az attrakciók tudatos vagy spontán átformálásával újul meg maga a desztináció. Az újrapozícionálás legköltségesebb változata a funkcióváltás, ami korábban nem turisztikai céllal hasznosított terek turisztikai célú használatbavételét jelenti (turisztikai célú barnamezős beruházások, pl. Ruhr-vidék, Pécs-Zsolnay negyed).

A desztináció-megújulás lehetséges módjait tekintve véleményünk szerint három fó irányvonal vázolható fel, ami alapvetően a kínálati oldalról indulhat ki. Így egyrészt beszélhetünk az attrakció, másrészt a kapcsolódó szolgáltatások (elsődlegesen a szúken vett fogadóképesség), illetve harmadrészt a menedzsment megújulásáról. A fenti tipológia tiszta formájában ritkán valósul meg, általában több irányvonal együtt jelenik meg. Tanulmányunkban egy magyarországi desztináción keresztül kívánjuk mindezt bemutatni. A mintaterület kiválasztását meghatározta, hogy olyan desztinációról van szó, amely a turisztikai piacon az 1970-es években jelent meg, a korszak kelet-közép-európai rekreációs térfejlesztési mintáját követve (CSORDÁs L. 1993; SzÖRÉNYINÉ KUKORELLI I. 2010), majd gyors felfutás után a 2000-es években benne a hanyatlás jelei mutatkoztak. A 2000-es évek végén több, alapvetően belső tényezőnek köszönhető, újabb növekedési pálya rajzolódik ki.

\section{Az orfúi desztináció fejlődése a kezdetektől napjainkig (desztinációs életciklusok)}

A mai orfúi desztináció története a szocialista korszak extenzív iparosítási és urbanizációs szakaszával esik egybe, amikor a gyorsan növekvő városi lakosság szabadidejének lekötésére tervezett rekreációs tereket hoztak létre Magyarország-szerte (AUBERT A. et al. 2013). Ebbe a típusba tartozik az ország déli részén, a Mecsek északi előterében fekvő, Pécs rekreációs zónájába tartozó Orfü, amelynek rekreációs térré történő fejlesztése egészen az 1960-as évekre nyúlik vissza. A fejlesztéseket az akkor még öt önálló településból álló, többnyire agrártevékenységgel foglalkozó orfúi térségben a Baranya megyei Tanács kezdeményezte. A fejlesztés bázisául a kiváló természeti adottságok szolgáltak, amit a négy tóból álló tórendszer kialakítása is megerősített. Az egyes tavakhoz már a tervezés fázisában funkciókat rendeltek (pl. az Orfúi- és a Pécsi-tó a rekreáció és a vízparti turizmus, a Herman Ottó-tó a hal- és madárrezervátum, a Kovácsszénájai-tó a horgászat céljait szolgálja, ami megalapozza fejlesztésük irányát is. A tórendszer 1962 és 1970 között épült ki, ez az időszak a desztináció életében az alapozó fázist jelenti. Ekkor zajlott a települések infrastrukturális fejlesztése, illetve a turisztikai vonzerők alapjainak kiépítése is.

Az 1970-es években történt a tóparti telkek parcellázása, a „második otthonok” (CsORDÁs L. 2012) építése az Orfúi- és a Pécsi-tó partján; megindult a korszakra jellemző szociál- 
turizmus, ami egyrészt a vállalati/szakszervezeti, másrészt az ifjúsági turizmus (gyerektáboroztatás) formájában öltött testet. Ez egyúttal a desztináció új fejlődési szakaszaként, a bekapcsolódás fázisaként értelmezhető. Az alapvetően vállalati üdülőkre, magán-szállásadásra épülő vendégfogadás azonban nem tette lehetővé a vendégforgalom jelentősebb bővülését, ahhoz kereskedelmi szálláshelyek megjelenésére volt szükség.

Ennek első lépése egy nagyobb fogadókapacitású kemping létesítése volt (1982), amelynek nemzetközi piaci megjelenésével, a Mecsek Tourist beutaztató tevékenységének köszönhetően a desztináció vendégköre átstrukturálódott. A korábbi belföldi vendégkör mellett elsősorban német és holland vendégek jelentek meg nagyobb létszámban. A desztináció fejlődésének következő állomása a legnagyobb tó (Pécsi-tó) partján található fürdő kiépítése volt (1985), a kemping és a fürdő térben erősen koncentrált fejlesztése egyértelmúen erősítette egymást és további növekedést hozott a település számára. Ez az évtized egyértelmúen a fejlódés fázisaként értelmezhető, ami mind a bel- és külföldi vendégek összetételében, mind a szálláshely-struktúrában (kereskedelmi és magán-szálláshelyek) megmutatkozott.

Az 1980-as évek végén a konszolidálódás jelei mutatkoztak, ami egyfajta érettségi fázisra utal. A vendégek és a vendégéjszakák száma ugyan tovább növekedett, azonban a kapacitásbővülés lefékeződött. Külső körülmények hatására ez a fázis rendkívüli módon lerövidült, nem követte a magasabb szinten beálló stagnálás szakasza, mint ahogy ezt a Butler-modell sugallja.

A 90-es évek első felében a társadalmi-politikai rendszerváltás és a balkáni háború hatásaként a külföldi vendégkör drasztikus leépülése figyelhető meg.

Míg az 1990-es évek elején még csaknem 70 ezer vendégéjszakát regisztráltak - ebból 45 ezer volt a külföldi vendégéjszaka -, addig ez a szám 1995-re a harmadára esett viszsza; ez az arány a 2000-es évek elejéig meg is maradt (1.ábra, 1. táblázat). Ez az időszak egyértelmúen a hanyatlás fázisaként értelmezhető. Ennek ellentmond a szállásférőhelyek folyamatos növekedése az 1990-2005 közötti időszakban, ami nem jelent valódi fizikai szálláshely-bővülést, okait valójában az 1990 után megindult privatizációban kell keresnünk. A privatizált állami vállalatok megszabadultak szociálturisztikai létesítményeiktől, a privát szektor nagy részüket átminősíttette kereskedelmi szálláshelyekké. Ez a folyamat valójában átnyúlik a következő évtizedre, gyakori a többszörös tulajdonváltás is (1. a Baranya megyei Tanács üdülőkomplexumát). A magánszállások „,kifehérítése” pedig

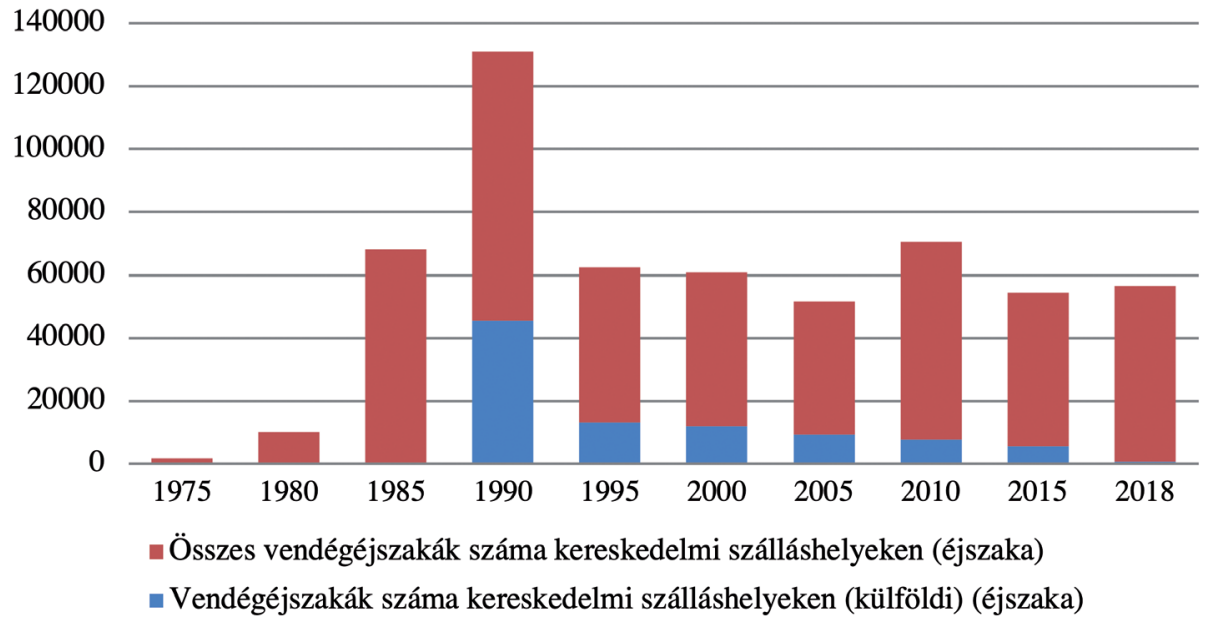

1. ábra A vendégéjszakák számának változása Orfún az 1975-2018 közötti időszakban. Forrás: KSH Figure 1 The number of guest nights in Orfú, 1975-2018. Source: HCSO 
A vendégéjszakák számának alakulása Orfú szálláshelyein

The number of guest nights spent at the accommodations of Orfü

\begin{tabular}{|c|c|c|c|c|c|c|c|c|c|c|}
\hline & 1975 & & 1985 & & 1995 & & 2005 & & 2015 & \\
\hline & & 1980 & & 1990 & & 2000 & & 2010 & & 2018 \\
\hline $\begin{array}{l}\text { Kereskedelmi } \\
\text { szálláshelyen eltöltött } \\
\text { vendégéjszakák } \\
\text { száma (külföldi) }\end{array}$ & n.a. & n.a. & n.a. & 45411 & 13087 & 11910 & 9336 & 7736 & 5404 & 609 \\
\hline $\begin{array}{l}\text { Kereskedelmi } \\
\text { szálláshelyen eltöltött } \\
\text { vendégéjszakák } \\
\text { száma (belföldi) }\end{array}$ & 1800 & 10000 & 68000 & 40113 & 36312 & 36862 & 32981 & 55101 & 43534 & 55225 \\
\hline $\begin{array}{l}\text { Egyéb (2009-ig ma- } \\
\text { gán) szálláshelyen } \\
\text { eltöltött vendégéjsza- } \\
\text { kák száma (külföldi) }\end{array}$ & n.a. & n.a. & n.a. & n.a. & n.a. & 2072 & 711 & 912 & 3129 & 3116 \\
\hline $\begin{array}{l}\text { Egyéb (2009-ig ma- } \\
\text { gán) szálláshelyen } \\
\text { eltöltött vendégéjsza- } \\
\text { kák száma (belföldi) }\end{array}$ & 1900 & 2100 & 1800 & n.a. & n.a. & 12362 & 7810 & 23098 & 19141 & 21883 \\
\hline $\begin{array}{l}\text { Összes vendégéjsza- } \\
\text { kák száma }\end{array}$ & 3700 & 12100 & 69800 & 85524 & 49399 & 63206 & 50838 & 86847 & 71208 & 80833 \\
\hline
\end{tabular}

\section{Forrás/Source: KSH/HCSO}

a helyi önkormányzatok érdeke is volt (a helyi idegenforgalmi adóbevétel minden forintjához az állam ebben az időszakban két forinttal járult hozzá).

1995 után mérséklődött a hanyatlás, a desztináció veszített vonzerejéből, a vendégkör átstrukturálódott, döntően a belföldi vendégkörre, ezt az időszakot nevezhetjük a hanyatlást követő, de alacsonyabb szinten beálló stagnálás fázisának. Az elavult vonzerőbázis és fogadókapacitás mellett maga a desztináció alapját jelentő tórendszer is rekonstrukcióra szorult. A Pécsi-tó medrét 2006-2007-ben kikotorták, azonban a 2007.év rendkívül száraz nyara után csak lassan töltődött vissza az optimális vízszintre. 2007-ben a tóba épített élményfürdő sem nyithatott ki, tömeges kagylópusztulás zajlott le és nagyon sok vendéget vesztett a desztináció.

Egyértelmúvé vált, hogy a desztinációnak átfogó megújítási stratégiára van szüksége, aminek kereteit a környezet terhelhetôsége, maguk a táji adottságok és a természeti, kulturális értékek jelölték ki. Tanulmányunk középpontjában a megújulási stratégia vizsgálata áll, ami 2008 óta új fejlődési pályára állította Orfút.

Ha a fentebb leírt folyamatokat a Butler-féle (1980) desztinációs életciklus-modellbe illesztjük, több nehézségünk is támad. Az egyes szakaszok elkülönítése különböző indikátorokkal lehetséges, amelyek közül a keresleti mutatók számszerúsítése egy olyan desztinációban, ahol a rekreációs funkció ilyen hangsúlyos, rendkívül nehéz. Ezért választottuk kiegészítésként JOHNSTON, C. (2011) modelljéből a kínálati mutatót, ami a szálláshelyek kapacitásával tagolja a desztinációs ciklusokat. Ezt bontottuk tovább a (magán-és kereskedelmi) szálláshely-kapacitás belső struktúrájával, mivel véleményünk szerint a rekreációs és turisztikai funkciókat egyaránt teljesíto desztináció fejlődéstörténetét jól reprezentálja. A desztináció-megújulás szorosan összefügg a termék- és szolgáltatás-életciklusokkal.E tekintetben támaszkodtunk ZiMMERMANN, F. (1997) modelljére (termék-életpályák), mivel esettanulmányunk nagyon jól példázza a megújulás fázisában ezen összefüggéseket (2. táblázat). A hivatkozott életciklus-modellek mellett primer kutatásokkal a megújulás fázisára koncentrálunk. 


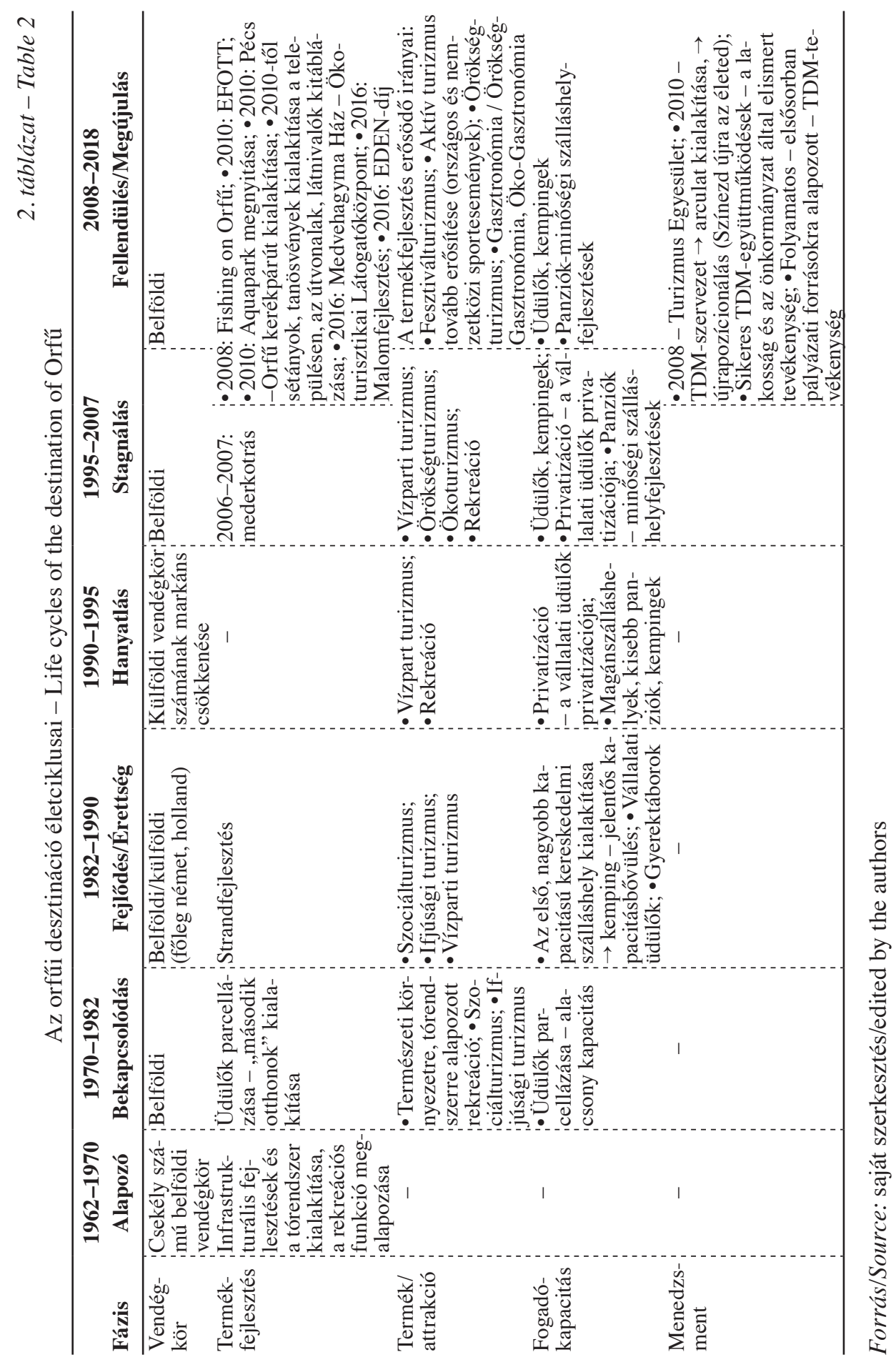


Az orfűi tórendszer mellett ma további három település alkotja a desztinációt (Abaliget, Husztót és Kovácsszénája), amelyek közül Husztót és Kovácsszénája nem rendelkezik érdemi turisztikai forgalommal és a desztinációhoz való kötődésük is elsősorban annak köszönhető, hogy Orfűvel egy körjegyzőséget alkotnak. Abaligetnek van még korábbról turisztikai funkciója, azonban ma ellentmondásos a helyzete a desztinációban. Az itt található mészkőbarlang gyógyászati célú hasznosítása korábban vált országos jelentőségúvé, ám fejlődése az 1990-es években megrekedt, az Orfűhöz hasonló turisztikai hasznosítás intenzitása elmaradt, a vendégéjszakákban mért forgalma az utóbbi években még a 10 ezret sem érte el. A település vezetése részéről nincs aktív turizmusfejlesztési szándék és a TDM-szervezet munkájában és finanszírozásában sem vesznek részt. Így kijelenthetô, hogy a desztinációhoz való tartozásuk formálissá vált, az együttmúködés csekély. Ennek köszönhetôen ma Orfü a motorja a desztináció fejlődésének, megújulásának, a további három település kiegészítő szerepet tölt be. Éppen ezért tanulmányunkban mind a $\mathrm{KSH}$-adatok vizsgálatának tekintetében, mind pedig a primer kutatás során Orfüre fókuszáltunk.

\section{Kutatásmódszertan}

Kutatásunk módszertani bázisát a szekunder forrásfeldolgozás mellett primer módszerek alkalmazása adja.

A vizsgálat primer módszertana három kérdőíves felmérésen alapul: a helyi lakosság és az üdülőtulajdonosok felmérése, valamint a szolgáltatói megkérdezés. A kérdőívezés célja mindhárom esetben a turizmus főbb folyamatainak vizsgálata (3. táblázat).

3. táblázat-Table 3

A kérdőíves felmérések jellemzői

Features of the questionnaire surveys

\begin{tabular}{lll}
\hline & Sokaság nagysága & Minta nagysága \\
\hline Lakossági felmérés & 1000 fó & 120 fő \\
Szolgáltatói felmérés & 65 szolgáltató & 65 szolgáltató \\
Üdüloótulajdonosok felmérése & 1600 & 156 üdülőtulajdonos \\
\hline
\end{tabular}

Forrás/Source: saját szerkesztés/edited by the authors

A lakossági felmérés alapsokaságát az Orfün állandó lakosként bejelentett népesség adta, ami megközelítette az 1000 főt. A minta nagyságát 120 főben határoztuk meg. A település egyes részeinek eltérő turizmus-intenzitását lényegesnek tartottuk beépíteni a reprezentativitás érdekében, így valamennyi településrészen történt anketőrös lekérdezés az adott településrész lakosságszámának arányában. A szolgáltatói felmérés keretében a teljességre törekedtünk az alacsony elemszám miatt, a szolgáltatók megkérdezése online kérdőív segítségével történt. Az üdülőtulajdonosok körében végzett felmérés során az 5\%-os mintanagyságot tűztük ki célul. Ebben az esetben is valamennyi üdülőzóna érintve volt a felmérés során, amit ugyancsak kérdezőbiztosok segítségével végeztünk.

A három felmérés során az adott szegmens jellemzőihez igazítottuk a kérdőívet, amelyben több azonos kérdés is szerepelt. Ennek köszönhetően egymással közvetlenül összevethetô válaszokat is kaptunk egy-egy témában. 


\section{Eredmények}

\section{Attrakció központú megújulás}

Az attrakció a turisztikai kínálat megahatározó eleme, amely a desztináció-építés középpontjában is áll. A megújuló desztinációknak egyik kulcseleme lehet, ami a megújulás folyamatában kitüntetett szerepet kap. Az attrakció központú megújulás lehet egyrészt a korábbi profilhoz illeszkedő, illetve attól alapjaiban eltérô. Orfú esetében a megújulás a korábbi arculathoz illeszkedő attrakciók fejlesztésével indult meg. A desztináció megújításában három alapüzenet fogalmazódik meg, ami egyúttal a terület pozícionálására is utal: „Színezd újra az életed!”, „Nagy élmények kis távolságra” és „Fedezd fel újra!”. Egyértelmúen látható, hogy mindhárom szlogen a megújulásra, illetve a desztináció újbóli felfedezésére koncentrál (4. táblázat).

4. táblázat-Table 4

Szlogen, üzenet és célcsoport az orfúi desztináció termékstratégiájában Basic message, slogan and target groups in the product strategy of the Orfú destination

\begin{tabular}{lll}
\hline Szlogen & Üzenet & Célcsoport \\
\hline „Színezd újra az életed!” & $\begin{array}{l}\text { megújulás, változatosság, } \\
\text { élmények }\end{array}$ & $\begin{array}{l}\text { felfedezók, újra felfedezók, } \\
\text { aktív utazók }\end{array}$ \\
„Nagy élmények, & élmények, közelség & $\begin{array}{l}\text { élményre és aktív kikapcsoló- } \\
\text { dásra vágyók, a környék lakói } \\
\text { kis távolságra” }\end{array}$ \\
„Fedezd fel újra!” & megújulás, élmények & $\begin{array}{l}\text { korábban itt járt vendégek, } \\
\text { visszatérók, a környék lakói }\end{array}$ \\
\hline
\end{tabular}

Forrás/Source: orfu.hu alapján saját szerkesztés

Ezek egyrészt a terület újrafelfedezésére utalnak, másrészt a környékbeli települések lakóit - főképp a pécsieket - szólítják meg. Míg a 2010-es évek elején mindhárom alapüzenetet felhasználta az orfúi menedzsment, addig mára kizárólag a „Színezd újra az életed” szlogen maradt meg, ami a piaci pozícióváltás eredményességére utal.

A kutatás során valamennyi érintettet megkérdeztük, vajon mit tekintenek a desztináció turizmusának alapjaként. Az 1-10-ig terjedő skálán az 1 a leginkább fontos, míg a 10 a legkevésbé meghatározó tényezőt jelentette. A válaszadók szerint a desztináció alapja egyértelmúen a természeti környezet, hiszen a vízhez kapcsolódó attrakciók és szolgáltatások képezik a terület fő profilját. A rekreációs tér 1960-as években meginduló fejlesztésének alapeleme is már ez volt, s amely a desztináció megújításában is vezetô szerepet kapott és folyamatos diverzifikáción ment keresztül. A kérdőíves felmérések alapján a helyi szereplők is mind egyetértenek abban, hogy továbbra is ezt az irányt kell tartani. A tavakon kívül legtöbben a védett természeti értékekben látják a desztináció jövőjét. Természetesen ez egyúttal korlátokat is jelent, hiszen a hosszú távú fenntarthatóság érdekében kiemelt figyelmet kell fordítani a táj terhelésének mértékére (2.ábra).

A természeti attrakciók - köztük a tórendszer - alapját képezik az aktív és passzív vízi turizmusnak, valamint a desztináció kivételes tájképi szépségét alapozzák meg. Orfú attrakciói közül a strandok bírnak szélesebb célközönséget is elérő, természeti alapú vonzerővel. Nem véletlen az sem, hogy a desztináció megújulását segítő vonzerőfejlesztések közül a természeti értékekhez kapcsolódó beruházásokra került sor a leghamarabb. A mai 


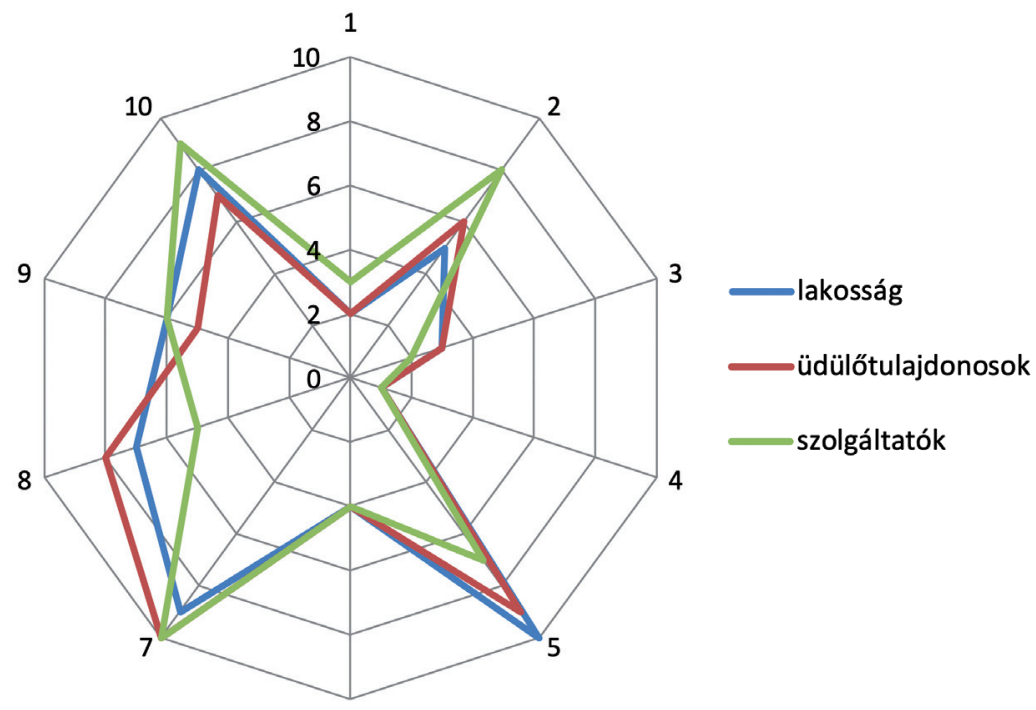

6

2. ábra Orfú turizmusának hosszú távú tényezői. Forrás: saját felmérés alapján saját szerkesztés.

- 1 - természeti tényezők, védett természeti értékek; 2 - kulturális értékek, látnivalók; 3 - aktív turisztikai kínálat; 4 - tavak, strandok, fürdőzési lehetőség; 5 - gasztronómiai kínálat; 6 - rendezvények;

7 - kellemes klíma; 8 - Orfú jó híre; 9 - gyermek- és családbarát környezet; 10 - megfelelő ár- és értékarány Figure 2 Long-term factors in the tourism of Orfú.

Source: edited by the authors, using their own questionnaire survey findings.

- 1 - natural factors, protected natural values; 2 - cultural values and sights; 3 - supply of sport tourism; 4 - lakes, beaches, bathing opportunities; 5 - gastronomic supply; 6 - events;

7 - pleasant climate; 8 - reputation of Orfü; 9 - children and family friendly environment; 10 - good value for money

desztináció megteremtésének alapja a Pécsi-tó 2006. évi mederkotrása, amit további fejlesztések egészítettek ki (sétány, tanösvények és kerékpárút kialakítása). A másik jelentős beruházás az Aquapark létrehozása volt, amely a korábbi strand fejlesztésének eredménye, s szintén EU-s közösségi forrás társfinanszírozásában készült el. Ez a valójában kisebb méretû aquapark mesterséges környezetével még jól illeszkedik a rurális táj karakteréhez. A másik jelentős fejlesztés az Orfüt Péccsel összekötő kerékpárút, amely 2010-2011 között készült, pályázati támogatással. A 2008-ben megalakult Orfüi Turisztikai Egyesület is aktívan szerepet vállal a szervezetfejlesztési projektek mellett a vonzerőfejlesztésben, így például rendezvények pályázati forrás bevonásával történő megvalósításával vagy egyéb tevékenységekkel (pl. attrakciók kitáblázása, kerékpártámaszok kihelyezése, felnőttjátszótér kialakítása stb.). A vonzerőfejlesztések a megalakulás óta is tartanak, ebben az önkormányzat és a TDM-szervezet forrásait hozzá kapcsolódó pályázati finanszírozás mellett a magántőke is kiegészítette. Ez egyértelmúen arra utal, hogy a fejlesztések megtérülése az elvárt időn belül várható és látható. A legújabban átadott projekt a térség természeti és kulturális értékeinek bemutatására hivatott és a Mecsek emblematikus, a helyi gasztronómiában változatosan hasznosított növényéről elnevezett Medvehagyma Ház, amely látogatóközpont funkciót is betölt.

Az elmúlt időszak termékfejlesztései négy irányban zajlottak, amelyek mind egy-egy profilt jelölnek ki, egyszersmind jól ki is egészítik egymást: „Zöld ritmusban - Természetesen”, „Kicsiknek és nagyoknak”, „Régmúlt idők varázsa”, illetve „Csepptôl a csobbanásig" (5. táblázat). 
Hívó szó és a turisztikai termék kapcsolatrendszere az orfűi desztinációban Relationships of profile and products in the destination of Orfü

\begin{tabular}{ll}
\hline Hívószó & Társított turisztikai termék \\
\hline Zöld ritmusban - Természetesen & ökoturizmus, természetjárás, kerékpáros turizmus \\
Kicsiknek és nagyoknak & rekreáció, ökoturizmus, passzív és aktív vízi turizmus, \\
& fesztiválturizmus \\
Régmúlt idők varázsa & örökségturizmus, fesztiválturizmus \\
Csepptől a csobbanásig & aktív és passzív vízi turizmus, horgászat, ökoturizmus \\
\hline
\end{tabular}

Forrás/Source: orfu.hu alapján saját szerkesztés

Jól látszik, hogy a természeti adottságok kapnak prioritást, de a múlt értékei is megjelennek a terület kínálati struktúrájában. A múlt értékei kevésbé az élettelen kultúra elemei közé (mindössze két múemléki védettséget élvező objektummal rendelkezik), inkább a megelevenített kultúra fogalomkörébe tartoznak, valamint a hagyományőrző programok és a tájra jellemző gazdálkodási formák és tevékenységek felelevenítése is elsőbbséget kap. Ehhez az irányvonalhoz illeszkedik a medvehagyma felhasználása az egyedi arculat kialakításában.

A desztináció legismertebb és leglátogatottabb attrakciója a Fishing on Orfü (FOO) könynyűzenei fesztivál, amelyet több értékelés a legjobb magyar könnyűzenei rendezvények közé sorol. Hatását a desztinációra egyértelmúen mutatja, hogy a rendezvény hónapjában a vendégéjszakák száma eléri Pécs városéit (OrOszi Gy. et al. 2018). Oroszi Gy. és szerzőtársai tanulmányukban részletesen kifejtik a FOO hatásait, például egyértelmú, hogy a fesztivál és programjai pozitívan hatottak Orfú imázsára, ugyanakkor elmondható, hogy a fesztivál vendégforgalma jelentős koncentrációt eredményez a statisztikákban, ami így „,torzítja” is a desztináció összképét, hiszen a desztináció növekvő vendégforgalma egyértelmúen és időben igen koncentráltan e fesztiválnak köszönhető. Tagadhatatlan azonban az is, hogy a fesztivál gazdasági előnyt is jelent, hiszen az idegenforgalmi- és iparúzésiadó-bevételek közvetlenül fejtik ki hatásukat. Jól látszik tehát, hogy a népszerű fesztivál sérülékennyé teszi a desztináció turizmusát, hiszen a fesztivál esetleges elmaradása turisztikailag nehéz helyzetbe hozná ezt a célterületet. Ugyanakkor éppen ez a fesztivál és a desztináció népszerúsége ösztönzi is az egyéb attrakciók és turisztikai termékek fejlesztését, amelyekre számos példát láthatunk, olyanokat is, amelyek egész évben elérhetővé és vonzóvá teszik a szóban forgó fogadóterületet (pl. ökoturizmus, Medvehagyma Ház mint attrakció és a hozzá kapcsolódó rendezvények).

A termékfejlesztés sikerességében kritikus tényező a helyi lakosság megítélése: menynyire vallja magáénak, mennyire ismeri el és látogatja az egyes attrakciókat, eseményeket. A kérdőíves felmérés alapján elmondható, hogy a helyi lakosok összességében kedvezően ítélik meg a helyi attrakciókat: szinte valamennyi helyszín értékelése meghaladta az 5-ös skálán a 4-es értéket. A leglátogatottabb orfúi attrakció a Kemencés Udvar, a Malommúzeum és a Medvehagyma Fesztivál. A helyiek leginkább a FOO fesztivállal, a Malommúzeummal és a Medvehagyma Fesztivállal elégedettek.

\section{Fogadóképesség és fogadókészség}

Az attrakciókhoz kapcsolódó megújulási törekvésekhez képest a fogadóképességhez kötődő fejlesztések hasonló súlyt képviselnek a desztinációk újjáéledésében. A fogadóképességben kulcsterület a szálláshelyi szektor, amely akár a turisztikai piac több szereplőjének funkcióját is át tudja venni. Ha fogadóképességről beszélünk, akkor annak minősé- 
gi és mennyiségi vonatkozásait is meg kell vizsgálni. Hanyatló desztinációk megújulása elsősorban a minőségi fejlesztésekhez köthető, hiszen a korábbi érettségi fázis már menynyiségileg magasabb szintű szálláshely-kapacitást igényelt. A fogadóképesség minőségi javítása után a fogyasztói igények kielégítése magasabb szinten valósulhat meg, ami új vendégkör megjelenését vonhatja maga után, illetve magasabb turisztikai bevételek realizálhatók a szolgáltatóknál és áttételesen az önkormányzat szintjén.

Orfün a szálláshelyek mennyiségének gyors növekedése az 1970-es években az üdülők építésével indult meg. Ekkor 282 lakott lakás mellett mindössze 105 „,csak nyáron lakott” ingatlan szerepelt. Később új, egyértelmúen rekreációs és az üdülő profilú településrészek keletkeztek. A 2001. évi adatok szerint 241 lakás mellett 1156 üdülőt regisztráltak a településen. Az üdülőkön kívül a szálláshelyi kapacitás bázisát az 1970-es évektől folyamatosan létrejövő kereskedelmi szálláshelyek jelentik.

Jelenleg a szálláshierarchia legmagasabb szintjét képviselő szálloda kategória nem található meg sem Orfün, sem a környező településeken. A jellemző szálláshelyek közé tartoznak a panziók és a kemping, míg a magán-szálláshelyek közül a fizetővendéglátásnak van meghatározó szerepe. Elsósorban tehát a kisebb egységek az uralkodóak, amelyek bár profiljukat tekintve jobban megfelelhetnek egy vidéki desztináció arculatának, a szervezett beutaztatásnak nem kedveznek.

A helyi lakosok véleménye alapján kiválónak (59,84\%) és jónak $(32,79 \%)$ minősíthetô a szálláshelykínálat Orfün, míg az üdülőtulajdonosok véleménye szerint 35-35\%-ban minősíthető kiválónak, illetve jónak. Azonban már lényegesen nagyobb szórás figyelhető meg, ha a jövőbeli veszélyforrások között becsülik meg a megfelelő szálláskínálat hiányának súlyát. A megkérdezett helyi lakosok 18,03\%-a szerint ez nagyon veszélyezteti, míg további 34,43\%-uk veszélyeztetettnek látja a desztináció jövőjét. A helyi szereplők egyetértenek abban, hogy középtávon mindenképpen szükséges olyan, a desztináció adottságaihoz illeszkedo, minőségi szálláshelystruktúra kialakítása, amely nagyobb kapacitást tud biztosítani a vendégforgalom számára.

A fogadóképességben a szálláshelyeken kívül a vendéglátás egységei is fontos szerepet kapnak. Orfún a vendéglátói és a kereskedelmi szektor nagyobb hangsúlyt kap, hiszen a fellelhető szálláshelyek közül kevés kínál teljes ellátást, ső́t nagy arányban egyáltalán nem biztosítanak étkezést, így azt a látogatóknak maguknak kell megoldaniuk. Élesedik a probléma, ha az egynapos látogatókat is figyelembe vesszük. A településen 6 étterem és 7 büfé üzemel, amelyek egy kivételtől eltekintve szezonálisan (május eleje és október vége között) tartanak nyitva. Orfú kiskereskedelmi ellátottsága azonban ennél is rosszabb, mindössze két bolt található a településen. A helyzetet jól tükrözik a vendéglátóipari és a kiskereskedelmi egységekkel való elégedettség számai és a változás igénye és szükségessége már minden szinten érzékelhető. A minőségi vendéglátás megteremtésére több törekvés, kezdeményezés figyelhető meg, például a minőségi gasztronómiát képviselő, helyi termékeket felhasználó éttermek megjelenésével.

A desztináció megújulásában a helyi szereplők kulcsszerepet kapnak. A turizmusban közvetlenül érdekelt helyi szolgáltatók felkészültségén kívül az önkormányzat és a lakosság attitűdje és együttmúködésük véleményünk szerint feltétele az egész desztináció sikerességének és egyben megújuló képességének. A felmérések alapján látható, hogy összességében a legkedvezőbbnek a lakosság látja a helyi szereplők hozzáállását. Magának az önkormányzatnak az elkötelezettségét a szolgáltatók ítélik meg a legkedvezőbben, ami egyértelmúen az önkormányzati szerepvállalásra is utal a turizmusfejlesztéseket illetően. A legalacsonyabb értéket a szolgáltatók saját felkészültségének értékelése $(3,47)$ érte el. A szolgáltatói felmérés alapján kiderül, hogy a szolgáltatások biztosítottak, de minőségük a jövőben mindenképpen javításra szorul (6. táblázat). 
Helyi szereplők hozzáállása a turizmushoz

Attitude of local actors to tourism

\begin{tabular}{lccc}
\hline & $\begin{array}{c}\text { A lakosság } \\
\text { vendégszeretete }\end{array}$ & $\begin{array}{c}\text { Az önkormányzat } \\
\text { elkötelezettsége }\end{array}$ & $\begin{array}{c}\text { A helyi vendégfogadók } \\
\text { felkészültsége }\end{array}$ \\
\hline Lakosság & 4,32 & 4,26 & 4,15 \\
Üdüloótulajdonosok & 3,95 & 3,55 & 3,92 \\
Szolgáltatók & 3,77 & 4,32 & 3,47 \\
\hline
\end{tabular}

Forrás/Source: saját felmérés alapján saját szerkesztés/edited by the authors, using their own questionnaire survey findings

A település fogadókészségében fontos szerepet kapnak a helyi szereplők között a civil kezdeményezések. Orfün mintegy 10 civil szervezet múködik, amelyek aktívan szerepet vállalnak a desztináció életében.

\section{A menedzsment szerepe a desztináció megújulásában}

A turizmus-menedzsment más irányultságú beavatkozási lehetőséget kínál a desztinációk megújítása során, hiszen ez alapvetően a meglevő erőforrásokra hagyatkozik, illetve ösztönzőleg hathat az előzetesen meghatározott jövőkép és célok mentén a desztinációban múködő turisztikai attrakciók és szolgáltatók fejlesztéseire, fejlesztési irányaira (BIEGER TH. 2005; LengYel M. 2008; RAICH, F. -ZeHRER, A. 2013). A különböző menedzsment-modelleknek éppen ezért az is a célja, hogy az egyes desztinációk életciklusát meghosszabbítsa, eltérô hálózatosodási módokon keresztül, sajátos menedzsment rendszerével elősegítse az újjászületés fázisát (Aubert A. et al. 2015a; ZEHrer, A.-RAICH, F. 2010).

A turisztikai desztináció menedzsment (TDM-) rendszer szervezeti megjelenése 10 éves múltra tekint vissza Magyarországon (LENGYEL M. 2008; AUBERT A. et al. 2009), hiszen a 2005-ben megjelent Nemzeti Turizmusfejlesztési Stratégia (NTS) fogalmazta meg és nyilvánította ki először a turizmusirányítás megreformálásának szükségességét. Nyugati, elsősorban osztrák és német példákat és szakirodalmat (FREYER, W. 1999; BIEGER, TH. 2005; ZEHRER, A. et al. 2005; LuFT, H. 2007) figyelembe véve kezdődött meg a rendszer kialakítása, amelynek alapelvei az alulról építkezés, a partnerség-kooperáció, a professzionalizmus és a (közös) finanszírozás (LENGYEL M 2008). Ezek az elvek a magyar turizmus irányításába alapvetően új szemléletet vittek az együttmúködést és a hosszú távú tervezést nélkülöző korábbi irányítással szemben. A TDM-szemlélet megjelenésére így hazánkban akár egyfajta paradigmaváltásként is tekinthetünk, amely fókuszba helyezte a desztináció alapú gondolkodást (AUBERT A. et al. 2016, 2017). Noha a TDM-pályázatok inkább a magas vendégéjszaka számú, jelentősebb desztinációknak kedveztek, a kisebb desztinációkban (AUBERT A. et al. 2015b), így például Orfú esetében (GONDA T.-SPIEGLER P. 2012, JóNÁs-BERKi M. et al. 2015) is máig múködő TDM-szervezet jött létre. Az Orfúi Turisztikai Egyesület tagjai, alulról jövő kezdeményezés nyomán, 2008-ban fogtak össze a helyi turizmus fejlesztése érdekében. A munka során közös, hosszú távú, stratégiai célokat tûztek ki a szereplők, amelyeket a szervezet operatív rendszere a múködés során mindvégig szem előtt is tartott. A menedzsment szervezet elmondása alapján a sikertényező az érintettek széles körú bevonása és a különböző csoportok közötti folyamatos érdekegyeztetés, valamint az összehangolt tevékenység. További bizonyítéka a szolgáltatók és a TDM-szervezet közötti jó kapcsolatnak, hogy a szervezeti tagok száma növekvő tendenciát mutat. A TDM-szervezet elmondása alapján, ha új turisztikai vállalkozás jelenik 
meg a térségben, akkor az az elsők között keresi fel tagsághoz csatlakozási szándékával a TDM-szervezetet, ami bizonyítja annak elismertségét és a szervezetbe vetett bizalmat.

Emellett nem titok Orfú esetében, hogy a TDM-szervezet kimagaslóan jó kapcsolatot ápol az önkormányzattal. Az önkormányzatok szerepe kulcsfontosságú lehet egy-egy desztináció esetében is (SCHULER, A. 2013), hiszen ha a desztináció adottságai, vonzerőés attrakcióbázisa megfelelő, a sikeres piaci jelenléthez elengedhetetlen az önkormányzat támogató hozzáállása, az önkormányzat és a TDM-szervezet, valamint a turisztikai szereplők közötti jó kapcsolat kialakítása. Orfún egyértelmúen látszik, hogy az önkormányzat turizmusbarát hozzáállása a siker egyik alapja. A szolgáltatói kérdőívet kitöltők kimagaslóan jónak ítélték meg az önkormányzat turisztikai irányú tevékenységét (átlagosan 4,32 pont), ami mindenképpen támogatólag hat a desztináció turizmusának menedzsment-tevékenységére és annak sikerességére. A válaszadók 53,5\%-a az 1-5-ig terjedő skálán ötös értékelést adott erre a kérdésre.

A TDM-szervezet elmondása alapján a tevékenységük szerteágazó, ami részben annak is köszönhető, hogy így a pályázati forrásoktól függetlenebb tevékenységet tudnak folytatni, ennek eredményeképpen a fenntartást segítő többletbevételekhez jutnak. Ilyen tevékenységek például a különböző termékfejlesztések és a hozzájuk kötődő feladatkörök ellátása (pl. az orfúi Medvehagyma Ház Látogatóközpont üzemeltetése és programokkal való megtöltése) vagy a marketingtevékenység, valamint a rendezvényszervezés. A TDM-szervezet emellett ernyőszervezetként múködik, a helyi szolgáltatókat, vállalkozókat, civil szervezeteket fogja össze munkája során. A TDM-szervezet tevékenysége nyomán megtörtént a desztináció újrapozícionálása, amiról fentebb már részletesen írtunk. Ennek része az átgondolt marketingstratégia, valamint egy egységes turisztikai termékportfólió. A TDM-szervezet munkatársa külön hangsúlyozta, hogy a desztináció sikerének egyik alapja a desztináció viszonylag kis mérete, ami a tagokkal az aktív és naprakész kapcsolatot, valamint a kínálat egységesebb koordinációját eredményezi. A Nemzeti Turizmusfejlesztési Stratégia 2030 kiemelten foglalkozik a desztináció- és termékfejlesztéssel. A dél-dunántúli régió desztinációi e dokumentum szerint nem szerepelnek a kiemelt fejlesztési térségek között. Az orfúi desztinációnak minden esélye meg lehet arra, hogy a jövőben Pécs-Mecsek térségének méltó helyére kerüljön, különösen az NTS 2030 termékfejlesztési prioritásai között szereplő ,„aktív és természeti turizmus" által, aminek termékváltozatait széles körben nyújtja az orfúi desztináció.

\section{Összefoglalás}

A klasszikus desztinációs életciklus-modellt (BUTLER, R. W. 1980) árnyaló, többoldalú megközelítés alkalmazásával kívántunk elemezni egy, a vendégösszetételében rekreációs és turisztikai céllal igénybe vett desztinációt. A megújulás fázisára koncentráló kutatás differenciált metódusával, a megújulás tényezőkre bontásával hozzájárult ahhoz, hogy az ilyen vegyes profilú desztináció a maga komplexitásában vizsgálható legyen.

A kutatásunk elején megfogalmazott négy hipotézisünkkel kapcsolatban az alábbi álláspontra jutottunk:

1. Az első hipotézisünk, ami szerint jelentős rekreációs funkcióval is rendelkező turisztikai desztinációk életciklusa némiképpen eltér a tisztán turisztikai funkcióval rendelkezőkétől, visszaigazolást nyert. Ezt a tanulmány 3. fejezetében részletesen bemutattuk.

2. A második hipotézisünket,--ami szerint a desztináció-megújítás eredményességét és gyorsaságát jelentősen befolyásolja, ha az attrakciófejlesztés, a fogadóképesség-javulás és menedzsmentstruktúra-fejlesztés egyaránt megvalósul-Orfü konkrét példája alátámasztotta. 
3. A harmadik hipotézisünk ami szerint a hanyatlás időszakában a vendégéjszaka-szám csökkenését kis fáziseltolódással követi a szálláshely-kapacitás csökkenése is, nem nyert visszaigazolást. Orfü esetében a rendszerváltást követő, elhúzódó privatizáció idején a jelentős vendégéjszakaszám-csökkenéssel párhuzamosan zajlott a szociális turizmus felszámolása, az állami és vállalati üdülők privatizálása, ami jelentős kereskedelmi szállásférőhely-bővülést eredményezett.

4. Orfüi kutatásunk során a negyedik hipotézisünk is visszaigazolást nyert. Ezért elfogadjuk, hogy újrapozícionálás akkor lehet sikeres, ha valós és reális helyzetértékelésen nyugszik és olyan turisztikai termékek fejlesztésére fókuszál, amelyekben a desztinációnak relatív előnye van más desztinációkkal szemben.

Orfún a kínálat oldaláról az attrakcióközpontú megújulás áll a folyamat centrumában, amihez a fogadókapacitás nagyságrendileg rendelkezésre áll, míg szerkezeti összetételében és minőségi mutatóiban csak részlegesen követi a turisztikai fejlesztéseket. A helyi lakosok, az önkormányzat, a turisztikai vállalkozók és a különböző civil szerveződések biztos háttérként szolgálnak aktivitásukkal és pozitív hozzáállásukkal mind a fejlesztések, mind a vendégfogadás szempontjából, amit 2008 óta aktív TDM-szervezet fog össze és koordinál. A helyi turisztikai menedzsment megjelenésével új korszak kezdődött a desztináció életében. Tevékenysége kihatott a forrásszerzésre, a helyi lakosság és szolgáltatók aktivizálására, a turisztikai attrakciók menedzselésére, az imázsváltás elindítására.

Mindezek hatásaként a kereslet nagyságrendje lassan elérte a „hőskorszak” statisztikai mutatóit, jelentős vendégkörváltozást is megélve. A mára döntően a belföldi piacból élö desztináció a vízparti üdülö-pihenófunkció mellett a rendezvényturizmus és az alternatív turizmus egyik hazai központja, amely az imázsváltás folyamatában csakfeszített menedzsmentmunkával tarthatja meg pozícióját a jövöben, miközben a vonzeröalapját képezö természeti környezet fenntarthatósága keretén belül kell tartania a fejlesztési projekteket.

\title{
Köszönetnyilvánítás
}

A tanulmány és a kutatás az Európai Unió, Magyarország és az Európai Szociális Alap társfinanszírozása által biztosított forrásból az EFOP-3.6.2-16-2017-00017 azonosítójú, „Fenntartható, intelligens és befogadó regionális és városi modellek” címú projekt keretében jött létre.

\author{
Aubert Antal \\ PTE TTK Turizmus Tanszék, Pécs \\ aubert@ttk.pte.hu \\ GONDA TIBOR \\ PTE KTK Marketing és Turizmus Intézet, Pécs \\ gonda.tibor@ktk.pte.hu \\ JÓNÁS-BERKI MÓNIKA \\ berkim@gamma.ttk.pte.hu \\ Bicsérdi Arany-Mező Zrt., Bicsérd \\ MóKuSNÉ PÁlfi ANDREA \\ PTE TTK Turizmus Tanszék, Pécs \\ palfia@gamma.ttk.pte.hu
}




\section{IRODALOM}

AnHolt, S. 2009: Handbook on Tourism Destination Branding. - UNWTO.

Aubert A.-Gonda T.-Horváth Z.-PÁlfi A. 2016: TDM szervezetek Magyarországon: múlt, jelen, jövő. - In: HANusz Á. (szerk.): Turisztikai jövőkép Szabolcs-Szatmár-Bereg megyében. SZSZBMFÜ, Nyíregyháza. pp. 77-90.

Aubert A.-JónÁs-BERKi M.-MÉsZÁros B.-SARKADi E. 2009: A TDM modell adaptálásának differenciált megközelítése. - In: HANusz Á. (szerk.): Turisztikai desztináció, ,desztinációs menedzsment”: a Nyíregyházán 2009. május 20-21-én megtartott konferencia előadásai. Nyíregyházi Fơiskola, Nyíregyháza. pp. 3-17.

Aubert A.-CSAPÓ J.-JónÁs-BERKi M.-PÁLfi A. 2015a: A turizmus térszerveződési típusai Magyarországon - Térszervező modellek a turizmusban. - In: TÉsits R. - AlPEK B. L. (szerk.): A mi geográfiánk: Tóth József emlékezete. Publikon Kiadó, Pécs. pp. 271-281.

Aubert A.-JónÁs-BERKi M.-PÁLFi A. 2013: A rekreációs terek turisztikai értelmezése és elterjedése Magyarországon. - In: KóKAI S. (szerk.): Tanulmánykötet dr. Dobány Zoltán főiskolai docens 60. születésnapjára. Nyíregyháza: Nyíregyházi Főiskola Turizmus és Földrajztudományi Intézet, Nyíregyháza. pp. 21-34.

Aubert A.-BARCZA A.-GondA T.-Horváth Z.-PÁLfi A. 2017: Paradigmaváltás(ok) a magyarországi turisztikai desztinációk fejlesztésében és menedzselésében. - Turizmus Bulletin 17. 1-2. pp. 15-25.

Aubert A.-JónÁs-BERKi M.-PÁLFi A. 2015b: A desztináció megújulás kérdései Magyarországon. - In: RÁTZ T.-Michalkó G. (szerk.): Kreativitás és innováció a turizmusban. Kodolányi János Főiskola; MTA CSFK Földrajztudományi Intézet; Magyar Földrajzi Társaság, Székesfehérvár; Budapest. pp. 223-232.

BIEGER, TH. 2005: Management von Destinationen - Lehr- und Handbücher zu Tourismus, Verkehr und Freizeit. 6. Auflage. OldenbourgVerlag, München-Wien.

BuHALIS, D. 2000: Marketing the competitve destination of the future. - Tourism Management. 21.pp.97-116.

BujosA, A.-Riera, A.-Pons, P. J. 2015: Sun-and-beach tourism and the importance of intra-destination movements in mature destinations. - Current Issues in Tourism 17. 5. pp. 780-794.

ButLER, R. W. 1980: The concept of the tourist area life-cycle of evolution: implications for management of resources. - Canadian Geographer 24. 1. pp. 5-12.

CsORDÁs L. 1993: Szabadidő lakások az Alföldön. - Tér és Társadalom 7. 3-4. pp. 77-104.

FAUlKneR, B. 2002: Rejuvenating a Maturing Tourist Destination: The Case of the Gold Coast. - Current Issues in Tourism 5. 6. pp. 472-520.

CsORDÁs L. 2012: A kereskedelmi szálláshelyek kapacitásának és forgalmának alakulása Magyarországon (1990-2010). - In: GYőRI F. (szerk.): A tudás szolgálatában - Földrajzi Tanulmányok Pál Ágnes Tiszteletére. Közép Európai Monográfiák 5. Egyesület Közép-Európa Kutatására, Szeged. pp. 47-61.

FrEYER, W. 1999: Tourismus Marketing: Marktorientiertes Management in Mikro- und Makrobereich der Tourismuswirtschaft. 2. Auflage. Oldenbourg Verlag, München-Wien.

GONDA T.-SPIEGLER P. 2012: Helyi szintű TDM szervezet múködésének alapelvei és gyakorlata Orfú példáján. - In: HANUSz Á. (szerk.): A turizmus területi dimenziói. Nyíregyházi Főiskola Természettudományi és Informatikai Kar Turizmus és Földrajztudományi Intézete, Nyíregyháza. pp. 55-67.

GONDA T.-RAFFAY Z.-CsóKA L. 2018: Orfü rejtett konvencionális turizmusa.- Turisztikai és Vidékfejlesztési Tanulmányok 3. 1. pp. 4-19.

HALl, D. 2009: Rejuvenation, Diversification and Imagery: Sustainability Conflicts for Tourism Policy in the Eastern Adriatic. - Current Issues in Tourism 11. 2-3. pp. 280-294.

HoRKAY N 2003a. Turisztikai márka és márkapolitika a desztináció-menedzsmentben, I. rész. Turizmus Bulletin 2003/1.

HoRKAY N. 2003b: Turisztikai márka és márkapolitika a desztináció-menedzsmentben, II. rész. Turizmus Bulletin $2003 / 2$.

Hovinen, G. 2002: Revisting the destination life cycle model. - Annals of tourism Research 29. pp. 209-230.

Johnston, C. 2001: Shoring the foundations of the destination life cycle model, Part 1: Ontological and epistemological considerations. - Tourism Geographies 3. 1. pp. 2-28.

JóNÁS-BERKi M.-PIRISI G.-BuZSIK K. 2015: Desztinációfejlődés - kiegyenlítődés vagy differenciálódás? - Településföldrajzi tanulmányok 4. 2. pp. 122-134.

Kotler, Ph. 2000: Marketing Management. Analysis, Planning, Implementation and Control. - Prentice Hall Inc.

KovÁcs P. 2004: Turizmusmarketing elméletben és gyakorlatban. Budapest-Székesfehérvár, Kodolányi János Főiskola.

KozaK, M. 2002: Destination benchmarking. - Annals of Tourism Research pp. 495-519.

LEE, K. 2001: Sustanable tourism destinations the importance of cleaner produktion. - Journal of Cleaner Production pp. 313-323.

LENGYEL M. 2008: TDM Működési Kézkönyv. Heller Farkas Főiskola, Budapest. 
LufT, H. 2007: Destination Management in Theorie und Praxis - Organisation und Vermarktung von Tourismusorten und Tourismusregionen. - GmeinerVerlag, Messkirch.

NTS 2005: Nemzeti Turizmusfejlesztési Stratégia 2005-2013. - Magyar Turisztikai Hivatal. Budapest.

Michalkó G.-RÁTz T. 2013: Rejtett dimenziók a Kárpát-medence turizmusában. - In: FriSNYÁK S.-GÁL A. (szerk.): Kárpát-medence: természet, társadalom, gazdaság. Bocskai István Gimnázium Nyíregyházi Főiskola Turizmus és Földrajztudományi Intézete, Nyíregyháza; Szerencs. pp. 463-476.

Oroszi Gy.-GondA T.-Máté A. 2018: Fesztivállátogatási szokások a Fishing on Orfü fesztiválon. - Földrajzi Közlemények 142. 1. pp. 122-136.

PAPP-VÁRY Á. 2009: Országmárkázástól a versenyképes identitásig. A country branding megjelenése, céljai és természete. - Marketing \& Management 43. 2. pp. 4-19.

RAich, F.-Zehrer, A. 2013: Einfluss der Besonderheiten und Ausprägungen touristischer Netzwerkeauf die Produktentwicklung. - Zeitschrift für Tourismuswissenschaft. 5. 1. pp. 5-21.

Ritchie, J. R. B.-Crouch, G. I. 2000: The competitive destination: a sustainability perspective. - Tourism Management 21. 1. pp. 1-7.

SCHUlER, A. 2013: Die Bedeutung von Governance für Verändungsprozesse von Destinationen. - Zeitschrift für Tourismuswissenschaft 5. 1. pp. 23-40.

SzIVA I. 2012: Versenyző együttmúködés és a turisztikai desztinációk versenyképessége. „Hol volt, hol nem volt...?". - Vezetéstudomány 43. 5. pp. 52-60.

SzIVA I. 2014: Milyenek a professzionális desztinációmenedzsment-szervezetek? Versenyképesség és desztinációmenedzsment dán tapasztalatok tükrében. - Turizmus Bulletin 16. 3-4. pp. 59-67.

SZÖRÉNYINÉ KUKORELLI I. 2010: A rurális tér átalakulása: szuburbanizáció, rekreáció. - In: HARDI T.-LADOS M.-Tóтн K. (szerk.): Magyar-szlovák agglomeráció Pozsony környékén. MTA RKK Nyugat-magyarországi Tudományos Intézet, Győr. pp. 43-49.

TôzSÉR A. 2010: Versenyképes turisztikai desztináció: új turisztikai versenyképességi modell kialakítása. Doktori értekezés. Miskolci Egyetem, Miskolc.

ZEHrER, A.-RAICH, F. 2010: Applying a life cycle perspective to explain tourism network development. - The Service Industries Journal 30.9-10. pp. 1683-1705.

Zehrer, A.-Pechlaner, H.-HölzL, B 2005: The Development of a Destination Management System (DMS) in South Tyrol. Anatolia. - An International Journal of Tourism and Hospitality Research 16. 2.pp. 147-161.

Zimmermann, F. 1997: Future Perspectives of Tourism: Traditional versus New Destinations. - In: OPPERMANN, M. (ed): Pacific Rim Tourism. CAB International, Wallingford. pp. 231-239. 